\title{
Assessment of School Fatigue, Leisure Time and Social Relationships in a Group of Teenagers From Two High Schools in Suceava
}

\author{
Adriana Albu ${ }^{1}$, Arina Bădăluțăă ${ }^{2}$ Florin Dima ${ }^{1}$ \\ ${ }^{1}$ "Grigore T.Popa" University of Medicine and Pharmacy, Iași, Romania \\ ${ }^{2}$ The Department of Public Health, Suceava, Romania \\ Correspondence: Florin Dima, "Grigore T.Popa" University of Medicine and Pharmacy, Iași, Romania. E-mail: \\ dimaflorin88@yahoo.com
}

Received: September 16, 2018

Accepted: October 11, $2018 \quad$ Online Published: October 22, 2018

doi:10.11114/ijce.v1i2.3706

URL: https://doi.org/10.11114/ijce.v1i2.3706

\begin{abstract}
School programs are frequently too demanding, so there is a good chance of school failure and chronic fatigue. The study was carried out on a group of 211 students from two high schools in the city of Suceava. A questionnaire was used that attempted to quantify school fatigue, passive and active leisure time, and social relationships. Fatigue occurs as a result of exceeding the body's exercise capacity. The situation is difficult for teenagers who have to adapt to school demands but who are also vulnerable to excessive levels of effort. Passive rest is done through night and daytime sleep. Numerous daily activities are commonly associated with reduced hours of sleep. There are situations where relaxing activities such as watching television programs and using the computer can become tiring. A long time spent on the computer can be associated with restricting social relationships, a phenomenon that must be evaluated more closely. Such studies are essential for maintaining student wellbeing and for ensuring proper school performance.
\end{abstract}

Keywords: fatigue, sleep, leisure time, group of friends

\section{Introduction}

Fatigue is a phenomenon that occurs when overcoming the body's effort capacity. It is a complex state with subjective and objective neuropsychic, neurosensory, neurovegetative and musculoskeletal symptoms, with visceral, endocrine and metabolic changes. This phenomenon quickly sets in when overloading the mental capacities of the students. Avoiding the onset of pathological fatigue requires the adoption of hygiene measures concerning intellectual work and general emotional support for the student. The student should be helped to organize daily work time as much as possible, paying particular attention to the individual rhythm of intellectual work and the need to alternate abstract and recreational activities (Cosmovici \& Jacob, 2008).

The schedule of a student's workday is frequently overloaded and includes: class hours; the time needed to prepare homework; sleep and rest; time for personal needs (personal hygiene, nutrition); leisure (time spent with friends on a walk, watching a movie etc.); other occupations (domestic activities, extracurricular programs). For high school students, the situation is often difficult because after a 6 to 7-hour school program there are another 2-3 hours for doing the homework. Often, school related activities can reach 8-9 hours per day; this is at the level of an adult's workload and even more. In this context, favorable conditions arise for triggering fatigue reactions that can easily become chronic phenomena, generating overload and even illness (Eftodi, Meşina \& Ferdohleb, 2013).

Educational specialists need to know these phenomena and try to adapt their curriculum to adolescents' actual capabilities. Any inadequacies can easily be associated with school failure, with the emergence of school results below a pupil's real potential (Cosmovici \& Jacob, 2008).

In recent times, a worrying phenomenon in Romania is represented by the lower number of students who graduate from high school and pass the baccalaureate exam. There are many young people who have had good school results during high school and fail to pass a baccalaureate exam or college entrance examination. This is a concerning phenomenon and should be studied much more carefully.

Intense high school workloads are associated with a reduction in the time spent on nighttime or daytime sleep (Miller, Jansen \& Jackson, 2017). Sleep is not interesting for the student who comes from school and wants to watch television programs or play on the computer. At present, the time spent by the students on the computer is increasing, and even 
cases of computer addiction are being diagnosed.

Specialists must pay special attention to young people who feel good only in front of the computer; which do not easily stop from gaming; spend an increasing amount of time in front of the computer; have difficulty focusing on school demands, with poor results; eat little and at irregular intervals; are unaware of body hygiene; suffer from insomnia and sleep disturbances. There are many situations in which adolescents' main source of information is the internet, which may favor the emergence of serious health problems such as those related to body appearance and identification with the current beauty ideal (Abalasei \& Trofin, 2016). These erroneous ideas can be major stressors in the life of an adolescent and can easily lead to a lifestyle that favors the onset of fatigue. Thusly, we should be mindful of not only the amount of free time activities but also the quality of such activities.

Insomnia also occurs easily in a noisy living environment, an uncomfortable room, or parents who go to bed late. The sedentary lifestyle favors the appearance of insomnia, while the active one in which sport is intense is associated with an adequate adjustment of the sleep-wake cycle. Unfortunately, the overloaded school schedule along with time spent on the computer leaves no time for systematic physical exercise (Clerget, 2012).

The period of adolescence is a fairly difficult one, which is why specialists in the field need to be careful and try to solve problems as they occur. In Romania there are few school psychologists and few doctors specialized in school hygiene, so solving problems specific to the age of adolescence is often difficult or impossible.

Objectives: Assessing the frequency with which fatigue occurs in students in the studied group and assessing the differences that occur / do not occur among the pupils based on high school and school year; quantifying the nighttime and daytime sleep; knowing the time allotted by students for watching television programs and playing computer games; studying the social relationships of the students (the group of friends) by asking questions about the number of friends and the time spent outside of school with them.

\section{Material and Methods}

The study was carried out on a group of 211 students from two high schools in the city of Suceava. There are 100 students from the Economic College and 111 young people from the National College. Students in the $9^{\text {th }}$ and $11^{\text {th }}$ grades, aged between 14 and 18, were interviewed. The studied group consists of 106 students in the $9^{\text {th }}$ grade and 105 in the $11^{\text {th }}$ grade. The studied group was randomly chosen according to the pupils' willingness to answer the questions in the questionnaire and to maintain anonymity. The questionnaire is not very large because in our country there is no custom of using such methods of study, so there is a risk of loss of students' interest in these problems. The current situation of Romanian education, where many young people do not complete high school studies (do not pass the baccalaureate exam) requires the implementation of such methods. The teenagers were asked to fill a questionnaire about the phenomenon of school fatigue, active and passive leisure time and social relationships (the group of friends). The questions were chosen based on the Health Behavior in School-aged Children (HBSC) international questionnaires (Godeau, Arnaud \& Navarro, 2008).

There were three questions about the presence of the phenomenon of school fatigue:

- Are you tired?: 1. Often, 2. Seldom, 3. Never;

- Compared to your colleagues, do you feel tired: 1. More often, 2. The same, 3. Less often;

- In the morning when you wake up, you feel: 1. Rested, 2. Tired, 3. Very tired.

Passive rest is achieved through sleep, and active rest is achieved through recreational activities. Until the age of 18 the body needs 9 hours of sleep per day in order to fully restore. Total sleep time is represented by nighttime sleep plus daytime sleep. The recreational activities are represented by watching television programs (TV) and playing computer games. These are activities that are recreational if they are practiced for a short time (at most 1 hour per day), but they become sources of fatigue when the young person spends many hours watching TV or using the computer. The questionnaire contains 4 questions about passive and active rest:

- How many hours do you sleep on average per night?: 1. 6-7 hours, 2. 7-8 hours, 3. Over 8 hours;

- Do you sleep in the afternoon?: 1. Every day, 2. Often, 3. Seldom, 4. Never;

- How many hours per day you spend watching television: 1. Zero, 2. 0.5-1 hours, 3. 2-3 hours, 4. 4-5 hours;

- How many hours a day do you spend on computer: 1. Zero, 2. 0.5-1 hours, 3. 2-3 hours, 4. 4-5 hours.

Social relationships have been assessed with the help of two questions about the group of friends, which is essential during adolescence:

- How many close friends do you have? 1. None, 2. One, 3. Two, 4. Three or more;

- In general, how many days per week do you go out with friends after school? 1. None, 2. 1 day, 3. 2-3 days, 4. 4-5 days, 5. 6-7 days. 
The results were processed using Pearson's Chi-Squared Test.

\section{Results}

We will insist on three essential elements represented by the phenomenon of fatigue, rest and the group of friends.

Fatigue is assessed by three questions about the presence of this phenomenon, the intensity with which it is perceived and when it occurs.

To the question, "Are you tired?" there are $61.61 \%$ "Often" responses which is worrying. The balanced response of "Rarely" is only present in one-third of the surveyed students (Table 1).

Table 1. Frequency with which fatigue appears in questioned students

\begin{tabular}{l|l|l|l|l}
\hline \multirow{2}{*}{ Answer } & Often & Seldom & Never & Total \\
\cline { 2 - 5 } & Distribution of cases based on high school & 6 & 100 \\
\hline Economic College & 49 & 45 & 1 & 111 \\
\hline National College & 81 & 29 & 7 & 211 \\
\hline Total & 130 & 74 & 7.31 & \\
\hline$\%$ & 61.61 & 35.07 & 3.31 & 106 \\
\hline \multicolumn{2}{l|l|}{ grade } & Distribution of cases based on school year & 5 & 105 \\
\hline $11^{\text {th }}$ grade & 55 & 46 & 2 & \\
\hline
\end{tabular}

Between the two high schools, the calculated differences are statistically significant for $\mathrm{p}<0.001\left(f=2, \chi^{2}=14.388\right)$ and draw our attention to the students from the National College.

Based on school year, the calculated differences are statistically significant for $\mathrm{p}<0.05\left(f=2, \chi^{2}=8.732\right)$ and draw our attention to the students in the $11^{\text {th }}$ grade. Students from the National College, especially those in the higher grade, often feel fatigue because their school activity is intense and is associated with the preparation for future exams.

Students talk to each other in class, so the answer to the question of the presence of fatigue as compared to classmates is also important. The result is very important because for the same school year the demands are the same (the curriculum is identical for all high schools of a particular academic program), but the students' reactions are different. In the majority of cases $(57.81 \%)$ the students chose "The same" option (Table 2 ).

Table 2. Frequency of fatigue compared to classmates

\begin{tabular}{|c|c|c|c|c|}
\hline \multirow[t]{2}{*}{ Answer } & More often & The same & Less often & Total \\
\hline & \multicolumn{4}{|c|}{ Distribution of cases based on high school } \\
\hline Economic College & 17 & 57 & 26 & 100 \\
\hline National College & 28 & 65 & 18 & 111 \\
\hline Total & 45 & 122 & 44 & 211 \\
\hline \multirow[t]{2}{*}{$\%$} & 21.32 & 57.81 & 20.85 & \\
\hline & \multicolumn{4}{|c|}{ Distribution of cases based on school year } \\
\hline $9^{\text {th }}$ grade & 15 & 62 & 29 & 106 \\
\hline $11^{\text {th }}$ grade & 30 & 60 & 15 & 105 \\
\hline
\end{tabular}

There are also $21.32 \%$ "More often" responses, answers that appear due to a higher concern of young people for school results or because of their increased vulnerability. Differences calculated by high schools are statistically insignificant $\left(\mathrm{p}>0.05, f=2, \chi^{2}=4.037\right)$ and those calculated by school year are statistically significant for $\mathrm{p}<0.01\left(f=2, \chi^{2}=9.472\right)$. In the $11^{\text {th }}$ grade demands are higher, even if the intellectual effort is close to that of an adult (17-18 years).

The last question connects to the next studied aspect; that of passive and active rest. If the student sleeps enough, they wake up rested in the morning. Such a situation is found in only $36.49 \%$ of cases - roughly, a third of the students. It is a worrying result because we are concerned about the risk of chronic fatigue (Table 3 ).

Table 3. Presence of morning fatigue

\begin{tabular}{|c|c|c|c|c|}
\hline \multirow[t]{2}{*}{ Answer } & Rested & Tired & Very tired & Total \\
\hline & \multicolumn{4}{|c|}{ Distribution of cases based on high school } \\
\hline Economic College & 41 & 49 & 10 & 100 \\
\hline National College & 36 & 54 & 21 & 111 \\
\hline Total & 77 & 103 & 31 & 211 \\
\hline \multirow[t]{2}{*}{$\%$} & 36.49 & 48.81 & 14.69 & \\
\hline & \multicolumn{4}{|c|}{ Distribution of cases based on school year } \\
\hline $9^{\text {th }}$ grade & 48 & 46 & 12 & 106 \\
\hline $11^{\text {th }}$ grade & 29 & 57 & 19 & 105 \\
\hline
\end{tabular}

Our attention is drawn to the $14.69 \%$ of young people who choose the "Very tired" option. These young people should be in the attention of teachers and psychologists (if they exist in school) in order to identify the causes of this 
phenomenon. Based on high school the calculated differences are statistically insignificant $\left(\mathrm{p}>0.05, f=2, \chi^{2}=3.694\right)$.

Based on school year the calculated differences are statistically significant for $\mathrm{p}<0.05\left(f=2, \chi^{2}=7.424\right)$ and draw our attention to the young people in the $11^{\text {th }}$ grade. Some students start preparing for the baccalaureate exam and the college entry exams from the $11^{\text {th }}$ grade, which explains the presence of more intense fatigue.

The results to the questions about the presence of school fatigue lead us towards the aspects of passive and active rest. Passive rest is represented by sleep and active rest is represented by the activities considered to be relaxing. Particular attention should be paid to activities considered "relaxation" because any exaggeration can lead to an exacerbation of fatigue.

The time that adolescents have to allocate to daily sleep is 9 hours. Only after the age of 18 it reaches 8 hours per day. Unfortunately, the result is not encouraging, because in most cases (60.00\%) young people get 6-7 hours of sleep per night, totally insufficient to restore the capacity for intellectual effort. The result of 7-8 hours $(33.17 \%)$ would be acceptable in the situation when young people sleep during the day.

It would be appropriate to manage more than 8 hours of sleep per night, but this result only occurs in $17.06 \%$ of cases (Table 4).

Table 4. Number of hours of sleep per night

\begin{tabular}{|c|c|c|c|}
\hline Answer & 6-7 hours & $7-8$ hours & Over 8 hours \\
\hline & \multicolumn{3}{|c|}{ Distribution of cases based on high school } \\
\hline Economic College & 42 & 39 & 19 \\
\hline National College & 63 & 31 & 17 \\
\hline Total & 105 & 70 & 36 \\
\hline \multirow[t]{2}{*}{$\%$} & 49.76 & 33.17 & 17.06 \\
\hline & \multicolumn{3}{|c|}{ Distribution of cases based on school year } \\
\hline $9^{\text {th }}$ grade & 45 & 35 & 26 \\
\hline $11^{\text {th }}$ grade & 60 & 35 & 10 \\
\hline
\end{tabular}

Differences calculated by high schools are statistically insignificant $\left(\mathrm{p}>0.05, f=2, \chi^{2}=4.652\right)$, but those calculated by school year are statistically significant for $\mathrm{p}<0.01\left(f=2, \chi^{2}=9.457\right)$ and again draw our attention towards the $11^{\text {th }}$ graders. Practically, fatigue occurs in grade 11 students due to intense school demands associated with an insufficient nighttime sleep.

Insufficient nighttime sleep can be offset by daytime sleep. Unfortunately, the students' situation is difficult because there are $38.38 \%$ negative responses and $47.39 \%$ of "Rarely" answers. Only in $14.21 \%$ of cases students are sleeping daily $(5.21 \%)$ or often $(9.00 \%)$ in the afternoon (Table 5).

Table 5. Frequency of afternoon sleep

\begin{tabular}{|c|c|c|c|c|}
\hline Answer & Every day & Often & Rarely & Never \\
\hline & \multicolumn{4}{|c|}{ Distribution of cases based on high school } \\
\hline Economic College & 1 & 4 & 47 & 48 \\
\hline National College & 10 & 15 & 53 & 33 \\
\hline Total & 11 & 19 & 100 & 81 \\
\hline \multirow[t]{2}{*}{$\%$} & 5.21 & 9.00 & 47.39 & 38.38 \\
\hline & \multicolumn{4}{|c|}{ Distribution of cases based on school year } \\
\hline $9^{\text {th }}$ grade & 6 & 6 & 40 & 54 \\
\hline $11^{\text {th }}$ grade & 5 & 13 & 60 & 27 \\
\hline
\end{tabular}

The situation is difficult because in this context it is not possible to recover the insufficient hours of nighttime sleep, which creates favorable conditions for the occurrence of a chronic state of fatigue.

Based on high school, the calculated differences are statistically significant for $\mathrm{p}<0.001\left(f=3, \chi^{2}=16.406\right)$ and draw our attention to the students from the National College who assign greater importance to daytime sleep. Based on school year the calculated differences are statistically significant for $\mathrm{p}<0.01\left(f=3, \chi^{2}=15.564\right)$ and point to the $11^{\text {th }}$ grade students who frequently feel tired and feel the need to combat this phenomenon through daytime sleep.

Active rest has been assessed by time spent on television programs and computer activities. They are relaxing activities if they do not exceed a certain amount of time. Television programs are not an option for $43.12 \%$ of teenagers. Also, $35.54 \%$ of " $0.5-1$ hour" responses appear (time considered acceptable). We must not overlook the $18.48 \%$ of young people who sit in front of the television screen 2-3 hours per day and the worrying $2.84 \%$ of young people who chose the "4-5 hours" option (Table 6). 
Table 6 . The time spent by students watching television programs

\begin{tabular}{|c|c|c|c|c|}
\hline Answer & Zero & $0.5-1$ hour & $2-3$ hours & 4-5 hours \\
\hline & \multicolumn{4}{|c|}{ Distribution of cases based on high school } \\
\hline Economic College & 35 & 40 & 22 & 3 \\
\hline National College & 56 & 35 & 17 & 3 \\
\hline Total & 91 & 75 & 39 & 6 \\
\hline \multirow[t]{2}{*}{$\%$} & 43.12 & 35.54 & 18.48 & 2.84 \\
\hline & \multicolumn{4}{|c|}{ Distribution of cases based on school year } \\
\hline $9^{\text {th }}$ grade & 44 & 37 & 21 & 4 \\
\hline $11^{\text {th }}$ grade & 47 & 38 & 18 & 2 \\
\hline
\end{tabular}

Between high schools the calculated differences are statistically insignificant ( $\mathrm{p}>0.05, f=3, \chi^{2}=5.258$ ), a result also obtained when considering school year $\left(\mathrm{p}>0.05, f=3, \chi^{2}=0.873\right)$. Television programs do not conform to the students' concerns, so they are not a good option for spending their free time.

Computer and internet browsing may be more interesting choices; however $30.80 \%$ of negative responses appear. Our attention is drawn to the $29.38 \%$ of adolescents who chose the "2-3-hours" option and even $11.37 \%$ who chose "4-5 hours". The situation is worrying for half of the questioned students who feel tired, sleep little, but spend too much time on the computer (Table 7).

Table 7. Time spent on the computer

\begin{tabular}{l|l|l|l|l}
\hline Answer & Zero & $0.5-1$ hour & $2-3$ hours & $4-5$ hours \\
\hline & Distribution of cases based on high school & 31 & 9 \\
\hline Economic College & 32 & 28 & 31 & 15 \\
\hline National College & 33 & 32 & 62 & 24 \\
\hline Total & 65 & 60 & 29.38 & 11.37 \\
\hline$\%$ & 30.80 & 28.43 & 40 & 10 \\
\hline $9^{\text {th }}$ grade & Distribution of cases based on school year & \multicolumn{5}{l}{} \\
\hline $11^{\text {th }}$ grade & 29 & 27 & 22 & 14 \\
\hline
\end{tabular}

Between high schools the calculated differences are statistically insignificant ( $\mathrm{p}>0.05, f=3, \chi^{2}=1.228$ ), and we find the same between school years $\left(\mathrm{p}>0.05, f=3, \chi^{2}=7.324\right)$. Most young people spend leisure time in front of the computer, which explains the insignificant statistical differences obtained.

We calculated the differences that occur between the time students spend on television and the time they spend on computers. We note the presence of $18.48 \%$ of young people watching $2-3$ hours of television and $29.38 \%$ who spend 2-3 hours per day on the computer; $2.84 \%$ of adolescents spend $4-5$ hours on television programs and $11.37 \%$ spend $4-5$ hours on the computer. The calculated differences are statistically significant for $\mathrm{p}<0.001\left(f=3, \chi^{2}=22.034\right)$ and underline the increased interest of young people in computer activities.

Sometimes young people socialize virtually, so they do not have time for real friendships (close, meaningful friendships outside the virtual world). In this context, it is important to quantify the existence of friends (one or two) or a group of friends (three or more) and the time spent with them out of school.

The group of friends is only present in $37.44 \%$ of cases. There are adolescents who have one (18.00\%) or two (31.75\%) real friends; a good result. We must not overlook the $12.79 \%$ of young people who choose the "Zero" option, something that underlines a preference for loneliness. They have no real friends that they can rely on and with whom they can spend quality time (Table 8). Friendships formed in high school are beautiful and sometimes last a lifetime.

Table 8. Number of true friends

\begin{tabular}{|c|c|c|c|c|}
\hline Answer & None & One & Two & Three or more \\
\hline & \multicolumn{4}{|c|}{ Distribution of cases based on high school } \\
\hline Economic College & 13 & 15 & 34 & 38 \\
\hline National College & 14 & 23 & 33 & 41 \\
\hline Total & 27 & 38 & 67 & 79 \\
\hline \multirow[t]{2}{*}{$\%$} & 12.79 & 18.00 & 31.75 & 37.44 \\
\hline & \multicolumn{4}{|c|}{ Distribution of cases based on school year } \\
\hline $9^{\text {th }}$ grade & 12 & 15 & 30 & 49 \\
\hline $11^{\text {th }}$ grade & 15 & 23 & 37 & 30 \\
\hline
\end{tabular}

Differences calculated by high schools are insignificant $\left(\mathrm{p}>0.05, f=3, \chi^{2}=1.293\right)$ as are those calculated by school year $\left(\mathrm{p}>0.05, f=3, \chi^{2}=7.343\right)$. Social relationships are influenced neither by high school nor by school year.

Students in the studied group do not have any differences in social relationships when considering either the high school or the school year. The presence or absence of the group of friends depends on the practical measure in which they adapt to the social changes specific to the teenage period. 
The existence of friends requires special time spent with them. We notice the $26.06 \%$ of students who choose the "Zero" option which is worrying because it shows a tendency towards social isolation. On the opposite end of the spectrum there are 5.21\% of young people who spend time with friends 6-7 days per week (Table 9).

Table 9. Days spent with friends

\begin{tabular}{|c|c|c|c|c|c|}
\hline Answer & None & 1 day & 2-3 days & 4-5 days & 6-7 days \\
\hline & \multicolumn{5}{|c|}{ Distribution of cases based on high school } \\
\hline Economic College & 27 & 26 & 36 & 7 & 4 \\
\hline National College & 28 & 33 & 32 & 11 & 7 \\
\hline Total & 55 & 59 & 68 & 18 & 11 \\
\hline \multirow[t]{2}{*}{$\%$} & 26.06 & 27.96 & 32.22 & 8.53 & 5.21 \\
\hline & \multicolumn{5}{|c|}{ Distribution of cases based on school year } \\
\hline $9^{\text {th }}$ grade & 30 & 28 & 35 & 7 & 5 \\
\hline $11^{\text {th }}$ grade & 25 & 31 & 33 & 11 & 6 \\
\hline
\end{tabular}

Differences calculated by high schools are statistically insignificant $\left(\mathrm{p}>0.05, f=4, \chi^{2}=2.192\right)$ as are those calculated by school year $\left(\mathrm{p}>0.05, f=4, \chi^{2}=1.656\right)$. True friends with whom students spend their spare time are not influenced by high school or the school year.

\section{Discussion}

The problem of school fatigue has to be carefully studied because it is often associated with school failure and the appearance of depression (Zilanawala, Sacker \& Kelly, 2017). In the studied group fatigue often occurs in $61.61 \%$ of cases. In a study carried out on a group of teenagers in Iasi on three types of high schools (theoretical, music and sports), fatigue is often present in 45.99\% of cases (Albu, Hodorca, Onose, Negrea \& Crăcană, 2016). Differences between high schools are statistically significant and draw attention to the theoretical high school students who feel more tired. It is a result similar to the one obtained in our study (the National College in Suceava is a theoretical high school) and raises some questions. Students from theoretical high schools (often considered the most prestigious type of high school in Romania) are probably more ambitious, more interested in school results and performance. These are important issues for a pupil's future, but need to be known and carefully followed by specialists in the field.

Most surveyed students (57.81\%) feel as tired as their colleagues. In another study carried out on adolescents from theoretical high schools in Iaşi, 60.18\% of such answers appear (Albu, Dima, Abdulan, Cărăuşu, 2018). It is an easily understood situation as these are students in the same class and have to face similar demands.

For both questions, students in the $11^{\text {th }}$ grade perceive a much more intense level of fatigue. Variations in intellectual effort capacity among different school years (age) were also observed in other studies. In a study carried out on medical students from a university in the Republic of Moldova, the capacity for memorizing numbers in the morning and afternoon decreases from $36.36 \%$ in the $4^{\text {th }}$ year, to $30 \%$ in the $3^{\text {rd }}$ year and $20 \%$ in the $2^{\text {nd }}$ year. The ability to focus increases in the second semester for students in the $1^{\text {st }}, 2^{\text {nd }}$ and $5^{\text {th }}$ years; in the $4^{\text {th }}$ year there is a decrease and in the $3^{\text {rd }}$ year the values remain the same (Eftodi, Meşina \& Ferdohleb, 2013).

The time spent sleeping is often insufficient, with adolescents in the studied group sleeping mostly 6-7 hours per night (49.76\%). A similar result was obtained in the study carried out in Iasi on three types of schools. In $75.94 \%$ of cases, they slept 6-7 hours per night. The calculated differences were statistically significant, drawing attention to theoretical high school students. In the current study, the differences between high schools are insignificant, but those calculated by school year are statistically significant probably due to preparations for the baccalaureate exam and the university entrance exam.

In a US adolescent study, average nighttime sleep values of 8.8 hours correspond to the recommendations of the specialists. Adolescents sleeping too little can resort to stimulants, alcohol or drug use, a situation that is undesirable (Miller, Jansen \& Jackson, 2017). They are also at risk of being involved in road accidents.

Leisure activities include watching television programs and playing computer games. The television programs are watched for $4-5$ hours by $2.84 \%$ young people, a better result compared to that obtained in adolescents from Iasi from different types of high schools where 6.32\% young people sit in front of the television for 4-5 hours every day. In the studied group there are $43.12 \%$ young people who choose the "Zero" option, while in the study in Iasi, the percentage of students choosing the "Zero" option is $22.78 \%$. In the population of our country viewing television programs has long been considered a basic element of leisure time. In an adult study, we can see the presence of $40.85 \%$ of 35-49-year-olds responding "rarely, almost never", and 23.6\% responded "often". At the age of 50-59, there are 38.9\% of "rarely, almost never" responses, and $34.0 \%$ of "often". Quitting watching television shows occurs both in adults and adolescents (Rada, 2017).

In 15-year-old teens in France, the time spent in front of the television is in most cases over 2 hours per day (54.9\% 
boys and $49.8 \%$ girls). Watching T.V. for $4-5$ hours per day is present in $14.3 \%$ boys and $19.4 \%$ girls. Overall, a large percentage of young people are sedentary (61.9\% at 15 years of age) and do not follow the recommendation to not spend more than 2 hours per day on television programs or other media (Godeau, Arnaud \& Navarro, 2008).

Students are interested in computer games and virtual socializing, so sometimes there is a risk of isolation and lack of real friendships (due to online ones). In the studied group, $11.37 \%$ of young people chose the " $4-5$ hours" option. In the study carried out in Iasi on three high schools, the percentage of pupils using the computer for 4-5 hours reaches $21.94 \%$. In a study carried out in the Republic of Moldova there are $14.6 \%$ of young people sitting at the computer 4-5 per day (Croitoru, 2015). In another study of pupils in Croatia, 14.009\% of young people are sitting in front of the computer screen 4-5 hours per day (Lazic, Pavlina \& Belovic, 2017). In our study, 26.06\% of young people opt for the "Zero" option and in the one carried out on three high schools in Iasi there were $11.81 \%$ of negative responses. There are no negative responses (they don't spend any time in front of the computer screen) in studies in the Republic of Moldova and Croatia, which is worrying because of the risk of computer addiction.

Family experiences from childhood are essential for developing balanced social relationships and avoiding loneliness (Faludi \& Dégi, 2015). In an adult study, 36.3\% of 35-49-year-olds reported to "rarely, almost never" meet with their friends or neighbors, and $24.8 \%$ meet "often". In persons aged 50-59, 38.15\% of negative responses and $35.3 \%$ of "often" answers appear (Rada, 2017). The lack of interest of adults in social relationships will also affect adolescents. The studied group has $12.79 \%$ of students who have no real friends and $26.06 \%$ of students who do not spend time out of school with them. In Japanese adolescents, preference for loneliness increases from $21.1 \%$ at 12 years to $35.7 \%$ at 18-year-olds in the male sex. In young women, the evolution is from $21.2 \%$ at 12 years old to $34.8 \%$ at 18 years of age. In both sexes the differences are statistically significant, demonstrating a worsening of the situation with age. In our study the differences calculated by school years are statistically insignificant. In a study carried out on adolescents in France, we observe $90.4 \%$ of young people with three or more friends and $0.7 \%$ of young people with no friends (Godeau, Arnaud \& Navarro, 2008).

In Japanese teenagers social isolation is present in $19.2 \%$ of boys aged 12 and $26.4 \%$ at 18 years of age. For young girls, social isolation is present in $12.6 \%$ of cases at 12 years and reaches $10.5 \%$ at 18 years of age, the statistical differences being insignificant in both sexes (Endo et al. 2017). In our study the differences based on age are statistically insignificant and show a similar tendency of social isolation.

\section{Conclusions}

Fatigue is particularly common in theoretical high schools and especially $11^{\text {th }}$ grade students. Frequently, young people feel tired in the morning after a small number of hours spent sleeping. The demanding activities during the day do not leave room for daytime sleep. In this context there is a risk of evolution towards a chronic phenomenon of fatigue and serious health problems.

Spending leisure time excessively on television programs or on the computer can be a situation that generates fatigue, not relaxation. Time spent with friends is important, but some young people have no friends, so they do not spend time with people their own age.

Such studies are important because they provide information about the school's demands and the social relationships of young people. Starting from such results, it is possible to develop strategies for rapid solutions to combat these problems.

It is necessary to develop such questionnaires and to standardize them for the population of our country. In-depth studies on statistically significant groups of students will allow for accurate knowledge of the situation and will help point towards possible solutions for current problems. We consider this study to be a pilot study that needs to be enhanced and widely applied.

\section{References}

Abălașei, \& Trofin, (2016). Considerations on the correlation between real body and body image. Timişoara Physical Education and Rehabilitation Journal, 9(16), 7-12. https://doi.org/10.1515/tperj-2016-0001

Albu, A., Dima, F., Abdulan, I., \& Cărăușu, M. (2018). Evaluation of School Fatigue and Social Relationships in a Group of Students from General Knowledge High Schools in Iasi Country. Education Journal, 7(1), 1-4.

Albu, A., Hodorcă, R. M., Onose, I., Negrea, M., \& Crăcană, I. (2016). The evaluation of scholar fatigue phenomenon and some factors that cause it on a group of teenagers from Iasi, Global Journal of Sociology: Current Issues, 6(2), 44-49.

Clerget, S. (2012). Criza adolescenței. Căi de a o depăși cu success. București:Ed TREI.

Cosmovici, A., \& Iacob, L. (2008). Psihologie școlară. Iași:Ed. Polirom. 
Croitoru, C. (2015). Activitatea copiilor la computer și cunoștințele copiilor și părinților despre activitatea la computer, în funcții și disfuncți ale familiei contemporane, coordinators: Rada, C., \& Faludi C. București:Ed. Universitară.

Eftodi I., Meșina, V., \& Ferdohleb, A. (2013). Modificările indicilor psihofiziologici ai oboselii la studenții USMF"Nicolae Testemițeanu". buletinul Academiei de Științi a Moldovei, 5(41), 36-40.

Endo, K., Ando, S., Shimodera, S., Yamasaki, S., Usami, S., Okazaki, Y., ... \& Nishida, A. (2017). Preference for Solitude, Social isolation, Suicidal Ideation and Self-Harm in Adolescents, Journal of Adolescents Health, 61, 187-191. https://doi.org/10.1016/j.jadohealth.2017.02.018

Faludi, C., \& Dégi, C. L. (2015). Impactul experiențelor familiale din copilărie asupra relațiilor romantice și singurătății la adolescenții din Romania, in Provocări ale familiei contemporane, coordinators Rada, C. \& Bistriceanu, P. C. București: Ed. Universitară.

Godeau, E., Arnaud, C., \& Navarro, F. (2008). La santé des élèves de 11 à 15 ans en France? 2006, Paris:editions INPES.

Lazic, L. J., Pavlina, P. A., \& Belovic, T. (2017). The interest of elementary school students in computer science. New Trends and Issues Proceedings on Humanities and Social Sciences, 4(1), 232-238. https://doi.org/10.18844/prosoc.v4i1.2260

Miller, M. B., Jansen, T., \& Jackso, K. (2017).The Prospective Association Between Sleep and Initiation of Substance Use in Young Adolescents. Journal of Adolescents Health, 60, 154-160. https://doi.org/10.1016/j.jadohealth.2016.08.019

Rada, C. (2017). Impact of some demographic parameters on leisure time and body weight. Anthropological Researches and Studies, 7, 111-121. https://doi.org/10.26758/7.1.12

Zilanawala, A., Sacker, A., \& Kelly, Y. (2017). Longitudinal Latent Cognitive Profiles and Psychosocial Well-being in Early Adolescence. Journal of Adolescents Health, 61, 493-500. https://doi.org/10.1016/j.jadohealth.2017.05.008

\section{Copyrights}

Copyright for this article is retained by the author(s), with first publication rights granted to the journal.

This is an open-access article distributed under the terms and conditions of the Creative Commons Attribution license which permits unrestricted use, distribution, and reproduction in any medium, provided the original work is properly cited. 